\title{
Addressal to the Rising Problem of Traffic Congestion in Kalimpong, West Bengal: Causes and Preventive Measures
}

\author{
Rosemary Subba \\ Department Of Geography, North Bengal St.Xaviers' College, Rajganj, Jalpaiguri, West Bengal \\ * Corresponding author email: subbarosemary@gmail.com
}

Received: 16 May 2020 / Revised: 04 June 2020 / Accepted: 08 July 2020 / Published: 09 July 2020

\begin{abstract}
When towns and cities grow or rather undergo urbanisation; there are innumerable impacts that arise out of this process. One such impact is the problem of traffic congestion. In other words, it can be said that 'urbanisation and problems related to traffic go hand in hand'. Kalimpong has witnessed urbanisation at an astounding rate largely due to improvement in tourism and its floriculture. However, the town is crippled by the problem of traffic congestion. Being a hill station, the topography and the structure of the town restricts the widening of the roads therefore making the practice of illegal parking common and the major factor for traffic congestion. In this paper, the problem of traffic congestion in Kalimpong town has been addressed. The reasons responsible for the problem has also been highlighted along with some suggestive preventive measures.
\end{abstract}

Keywords: Traffic congestion, illegal parking, encroachment, space crunch, narrow roads.

\section{Introduction}

Traffic congestion is one of the acute urban problems that torment many emerging large and small towns and cities arising especially due to increased private transportation, improper management-affecting societies, aggravating environmental pollutions and overall the process of development (Ye, 2012). Congestion refers to deferring caused by one vehicle to another when the volume of traffic is high at a particular road. The quintessence of traffic congestion in any area is the failure of the system to hold its traffic causing waiting and delays in road traffic. Moreover, as congestion continues to increase, the conventional approach of "building more roads" widening of roads doesn't always work for a variety of political, financial, and environmental reasons (Marve, Bhorkar, \& Baitule, 2016).

Kalimpong, a small hill station of North Bengal, is a popular tourist destination largely due to its favourable climate, proximity to other various tourist destinations, well recognised educational institutes, and floriculture. All these factors have attracted the people to congregate in this fast growing urban area which has led to intolerable traffic congestion on the streets for the last few decades (Rahane \& Saharkar, 2017). One lane roads, insufficient parking spaces, inefficient management, illegal parking are few of the reasons for traffic congestion that has caused distressed upon the local residents, visitors and one of the reasons that has hampered tourism in Kalimpong.

\section{Literature Review}

Transportation is not only a resource factor rather; it is a catalyst for the true development of various resource characters (Sarkar, 2013). Transportation, the movement and exchange of people, goods and services is an obligatory feature of modern life (Umoren, Ikurekong, Emmanuel, \& Udida, 2009) because of its multi-dimensional functions and importance keeping relations and making integrations among every aspect of a society ranging from an individual to a nation (Sarkar, 2013). While rebuilding any region or nation or country, roads always play a dynamic part, In essence, transport network is considered as a set of 
Addressal to the Rising Problem of Traffic Congestion in Kalimpong, West Bengal: Causes and Preventive Measures

interconnected route linking with numerous destinations within and the outside the region and provides a pace for movement of people and commodities (Sarkar, 2013). However, when this system gets crippled it not only affects everyday lives of the people but also causes slowing down of the developmental processes. Traffic congestion refers to the incremental delay caused by interactions among vehicles on a roadway, particularly as traffic volumes approach a roadway's capacity (Marve, Bhorkar, \& Baitule, 2016). If vehicles are fully halted for a longer duration, then it is termed as a traffic jam or traffic snarl-up (Suresh, Rao, \& Baraik, 2018). Traffic congestion wastes time and energy, causes pollution and stress, decreases productivity and imposes costs on society (Rao \& Rao, 2012).

Rao and Rao, states that there are two categories of factors of traffic congestion - micro level factors related to road problems and macro level factors related to demand of the road for its usages. Truly, in geographically restricted smaller areas or region where the number of roads one can adopt to reach its destination is limited and where substantial increase in population and vehicles is taking place, traffic congestion is bound to subsurface. This occurs mainly because of the poor road conditions, varying road way features, poor lane discipline, inappropriate bus-stop location and design, diversity of traffic, and unrestrained on-street parking (Vencataya, Pudaruth, Dirpal, \& Narain, 2018).

According to Maji, one of the oldest city of West Bengal- Asansol, is facing the problems of congestion and is largely attributed to improper planning, tremendous growth in population and illegal parking, and in big cities like Nagpur, according to Marve, Bhorkar \& Bitule, the main causes of traffic congestion is the exceeding of the volume of traffic by road capacity. Much like Asansol, the problems of traffic congestion in the study area can be attributed to these factors. Rahana and Shahakar, truly states that the impacts of traffic causes queuing, delay and increase in travel times, due to which there is an increase in economic cost which in turn gives birth to several multi-complex impacts on the concerned area. Theoretical frameworks and guidance on some of the practical tools necessary to manage congestion in such a way as to firstly to Avoid second to reduce and last but not the list mitigate the congestion its overall impact on individuals, families, communities and societies in urban areas (Marve, Bhorkar, \& Baitule, 2016).

\section{Methodology}

The information provided in this paper is largely based on the primary and secondary data. Firstly, the primary data were collected on the basis of the survey done on the study area with the help of questionnaires. The targeted population comprised of shopkeepers at the heart of the market, taxi drivers and private car owners, two wheelers holders, residents. For perception study on the matter, students and people traversing by foot were also surveyed. The primary data has been collected and analysed and using appropriate cartograms, has been represented in the paper. Secondly, the secondary data were collected from internets, already existing research works on similar matter in other areas.

\section{Background of the Study Area}

Kalimpong (Coordinates: $27^{\circ} 06^{\prime} \mathrm{N} 88^{\circ} 47^{\prime} \mathrm{E}$ ), a small hill station, in the state of West Bengal, embedded at the foothills of Shiwaliks, lying east of Teesta river, has an average elevation of $1247 \mathrm{~m}$ (4100 feet). The town also serves as the headquarters to Kalimpong sub division. As per 2011 census the population of Kalimpong is 49403 , and has a population density of $40.70 / \mathrm{km}^{2}$. Kalimpong has several roads and streets that provide connectivity and accessibility to the town (Figure 1-2). However, during peak hours it suffers massive congestion problems largely because of the imbalance between the carrying capacity of the roads and the number of vehicles. 
Rosemary Subba, Adv. J Social Sci.; Vol. 7, Issue 1, pp: 60-70, 2020

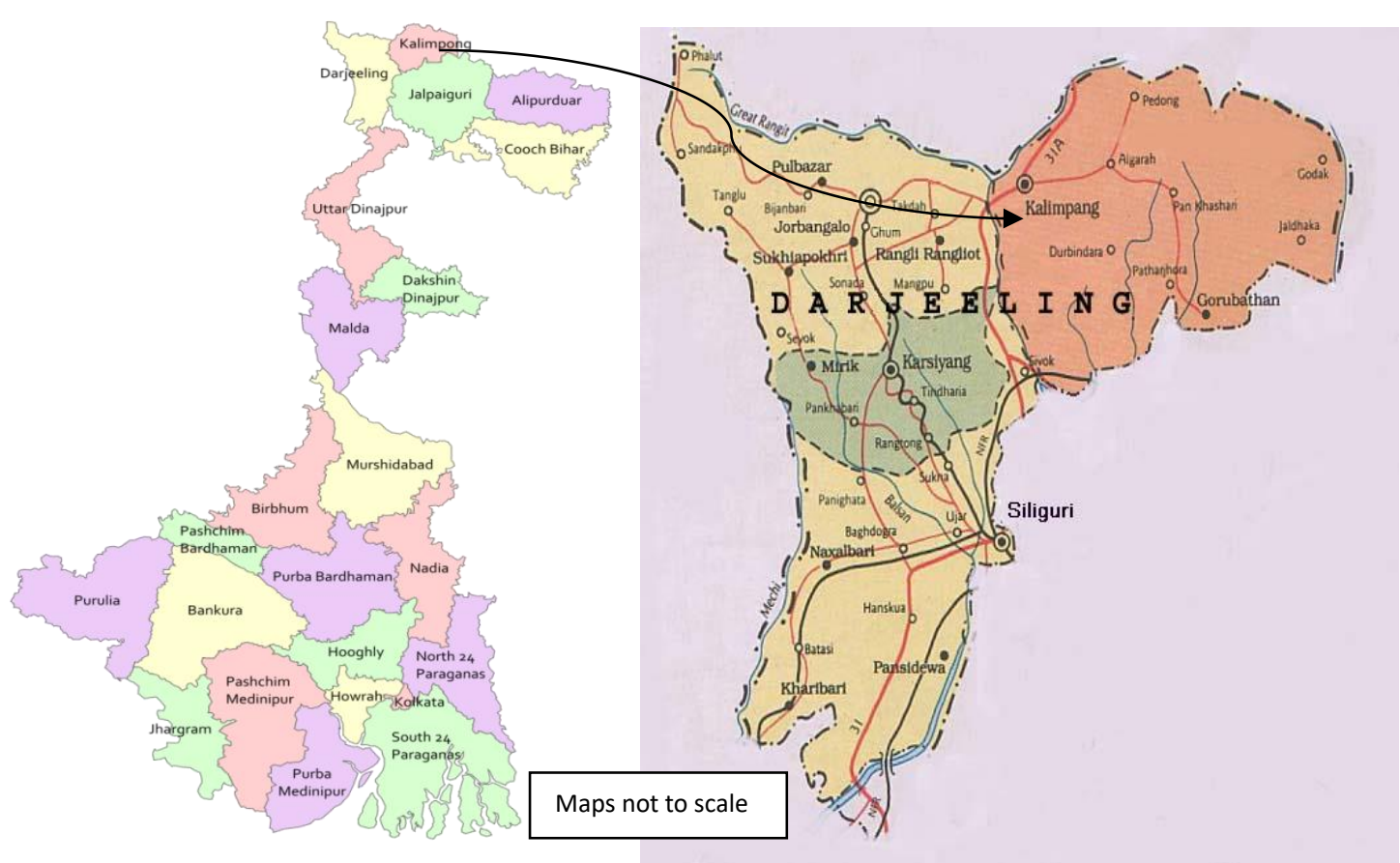

Figure 1: Map showing the state of West Bengal and the Kalimpong town (study area)

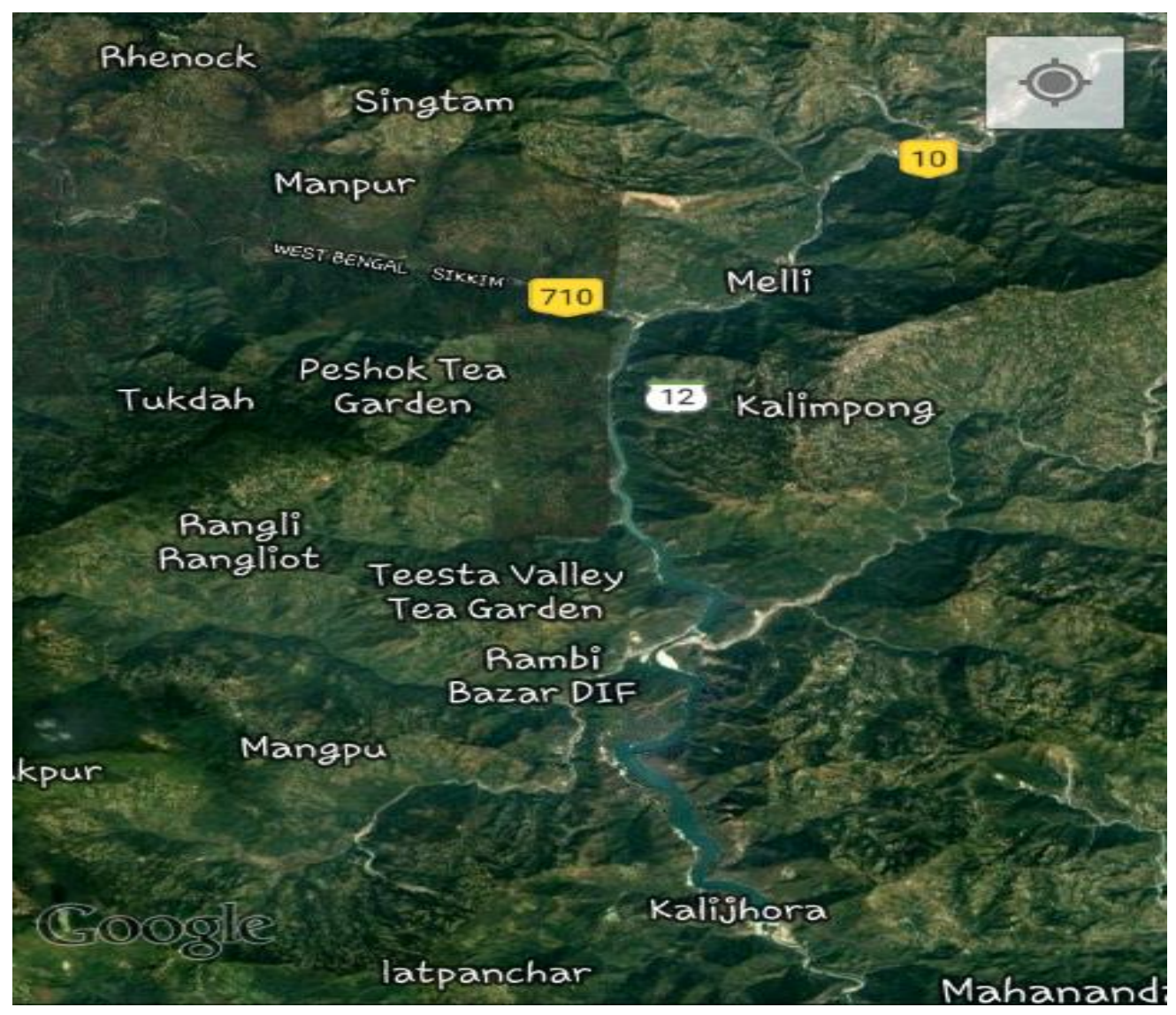

Figure 2: Google map showing the study area. 
Addressal to the Rising Problem of Traffic Congestion in Kalimpong, West Bengal: Causes and Preventive Measures

\section{Factors Responsible for Traffic Congestion in the Area}

The study and observation of the study area brought following factors into light responsible for traffic congestion: -

\subsection{Lack of parking spaces}

During the British times, a motor stand was developed above the Mela ground for the accommodation of vehicles. During that period, it was meant to hold 10-20 vehicles at a time (Figure 3). However, at present it holds more than 400 vehicles due to which a space crunch has taken place (Figure 4). These vehicles are those that take people plus goods to other different areas in and around Kalimpong and also to the neighbouring state of Sikkim and boarders of neighbouring countries like Bhutan and Nepal.

Due to lack of parking spaces, the vehicles are also parked in front of the Kanchan cinema which is at approx to the Aadarsh nursing home because of which people often face difficulties to move around. Another great example of space crunch can be seen along the main road (Dumber Chok to Supermarket building). The one side of the road is totally meant for the parking of the vehicles that connects the intercity.

In addition, there is no proper parking space for private vehicles that come to the town. They are usually parked along the roads in $10^{\text {th }}$ mile to the main town, below District Court, main road and along the roads of Novelty cinema hall and many more.
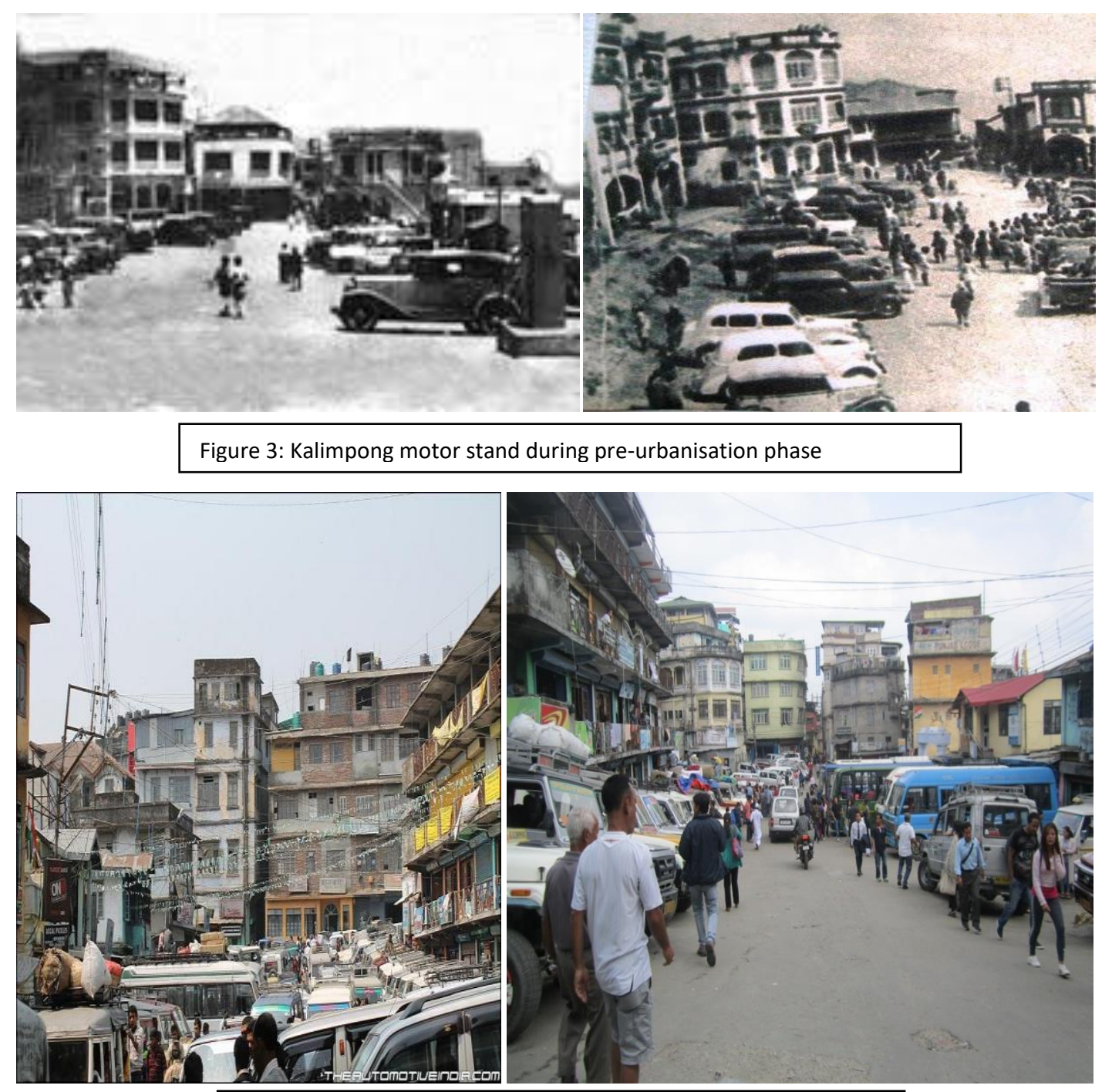

Figure 4: Current situation of Kalimpong motor stand. 
Rosemary Subba, Adv. J Social Sci.; Vol. 7, Issue 1, pp: 60-70, 2020

\subsection{Increase in the number of private vehicles}

As urbanisation has taken toll in this small town, the economic conditions too have climbed up therefore enabling people to own private vehicles. This increase in private vehicle have further increased the already existing pressure on space shortage.

\subsection{Narrow roads}

Owing to its topography, the roads of Kalimpong are rather narrow and the topography has restricted the expansion of the roads thus, parking of private vehicles, road side shops, people, etc makes these narrow roads more chaotic during the peak hours.

\subsection{Army trucks and heavy vehicles}

Traffic congestion is also caused due to passage of heavy vehicle through narrow road in most of the cases huge traffic is stuck for a longer duration (Suresh, Rao, \& Baraik, 2018). On the outskirts of the town, the Indian army's 27 mountain division is been located. The heavy army trucks (Shaktiman) has to traverse through the narrow roads of the town therefore several times causes distress on the traffic. Similarly, trucks that bring goods to the town also have to take the narrow road causing huge traffic congestion whenever it is in standby for longer period of time.

\subsection{Illegal parking}

Illegal parking is the major contributor to the problem of traffic congestion in the town. Lack of parking space has made the people to purposely or un purposely park along the roads, in front of the houses, shops etc. The one lane roads topped by road side parking have worsened the situation (Figure 5). Due to this traffic flow is interrupted and slows down the speed of vehicle until the wrongly parked vehicles are removed (Suresh, Rao, \& Baraik, 2018).
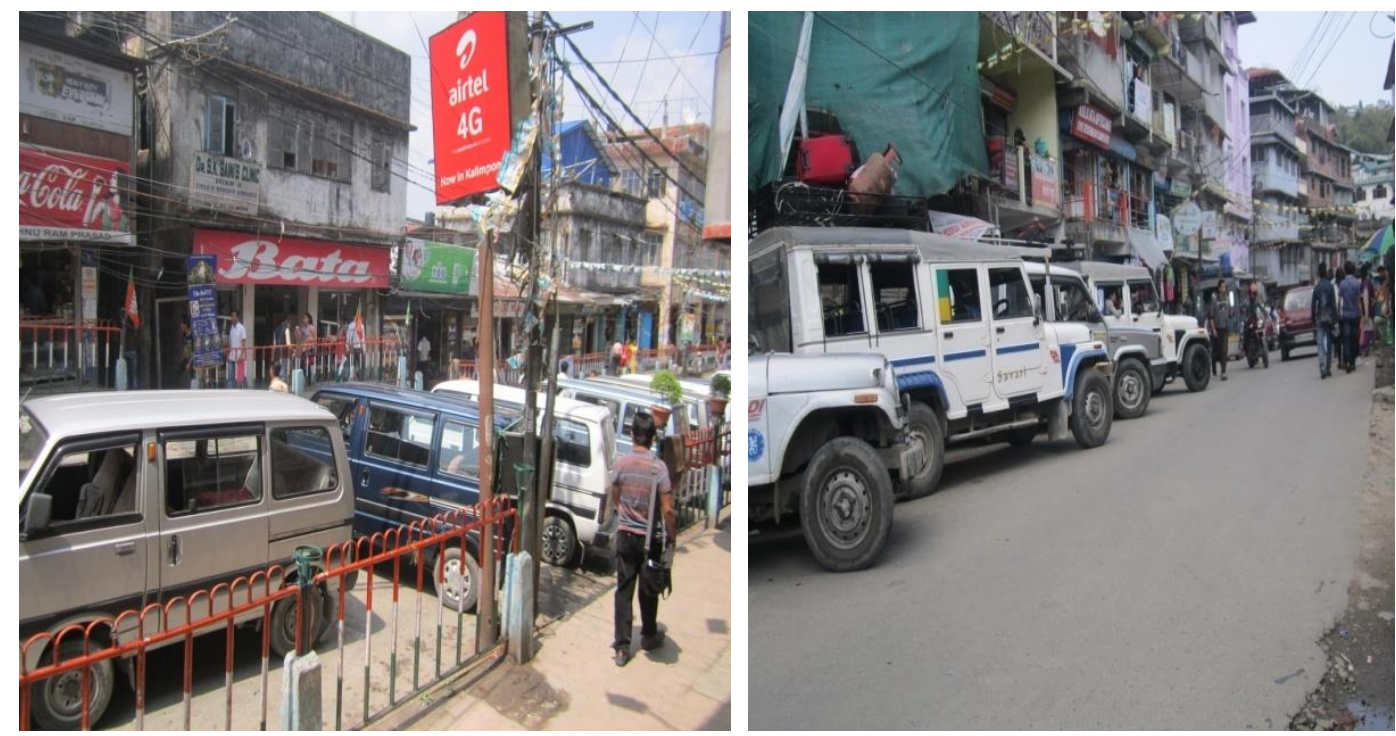

Figure 5. Roadside parking along main road and Kanchan cinema hall

Table 1. Datasheet to show number of vehicles parked in front of the house/shop.

\begin{tabular}{|l|l|}
\hline NUMBER OF VEHICLES PARKED & RESPONSES IN \% \\
\hline$<3$ & 47 \\
\hline $3-6$ & 43 \\
\hline$>6$ & 10 \\
\hline
\end{tabular}


Addressal to the Rising Problem of Traffic Congestion in Kalimpong, West Bengal: Causes and Preventive Measures

\section{NUMBER OF VEHICLES PARKED INFRONT OF THE HOUSE/SHOP}

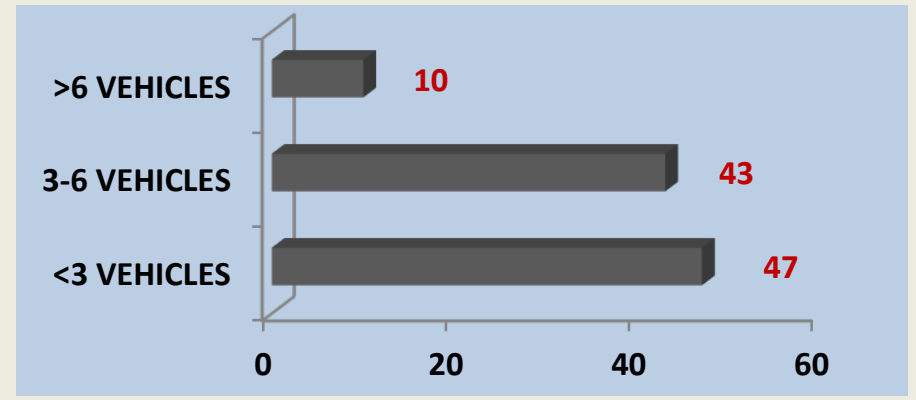

- NUMBER OF VEHICLES PARKED

Figure 6. Bar graph to show number of vehicles parked illegally in front of the house/shop

When the shopkeepers and residents of main road and kaancha cinema road were asked- 'per day how many vehicles are parked in front of their shops and houses', 47\% out of 70 surveyed household and shops told that 1-3 vehicles are parked while 10\% revealed that more than 6 vehicles are parked (Table 1, and Figure 6). When asked about the reasons why they park in front of their properties, they told that the lack of parking spaces was the cause for such situation. On further questioning regarding any complaints issued against this practice of illegal parking, most of them said 'yes', but authorities themselves are crippled due to absence of alternatives therefore much has not been done to overcome this problem.

Table2. Datasheet to show the responses of the house/shops against the duration of parking of vehicles.

\begin{tabular}{|l|l|}
\hline $\begin{array}{l}\text { Duration of parking of vehicles in front of the } \\
\text { house/shop }\end{array}$ & Responses in \% \\
\hline$<1 \mathrm{hrs}$ & 67 \\
\hline $1-3 \mathrm{hrs}$ & 23 \\
\hline$>3 \mathrm{hrs}$ & 10 \\
\hline
\end{tabular}

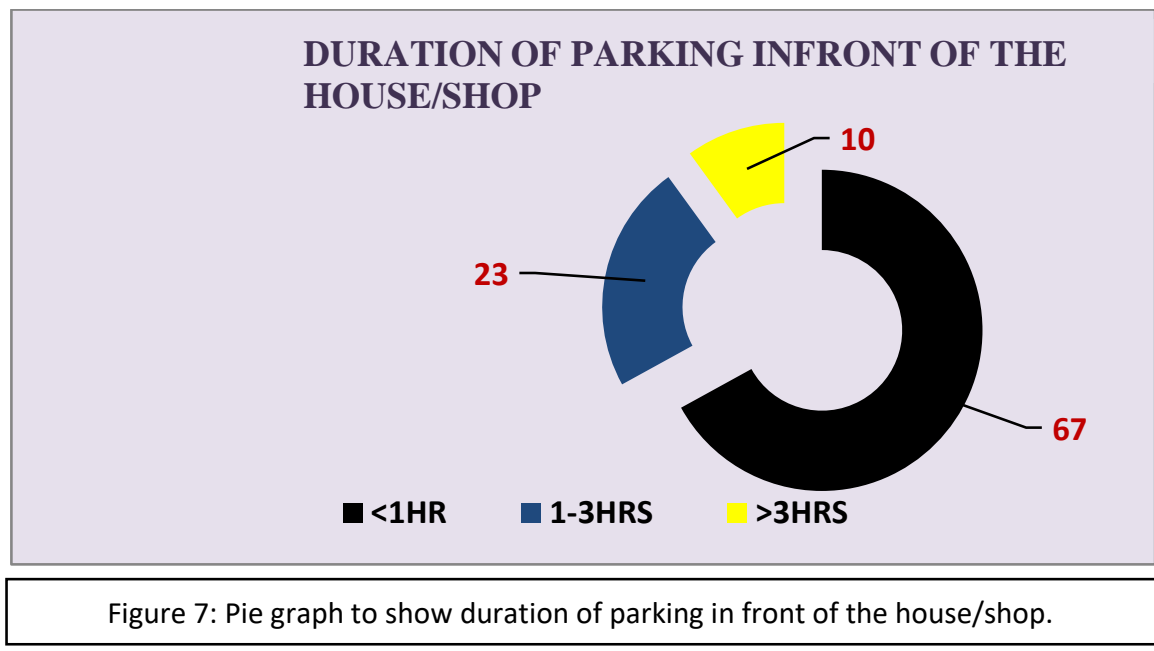

The shopkeepers and residents were also asked the duration of parking of the vehicles. $67 \%$ of them said the vehicles are usually parked for less than an hour since been a market area while $23 \%$ of them said parking is done for $1-3$ hours and 10\% agreed on more than 3hours (Table 2, and Figure 7). 
Rosemary Subba, Adv. J Social Sci.; Vol. 7, Issue 1, pp: 60-70, 2020

When the illegal parking is done in front of the house or shops, especially in the market area, a blockage on a certain portion of the road takes place therefore causing more distress on the road for other vehicles and public therefore fuels up the situation.

\subsection{Inefficient and insufficient traffic management.}

Strict actions are not taken to look after the matter. No proper planning has been done to manage the illegal parking. In the 2015s the construction of the parking complex had started below the Novelty cinema hall; however, its completion has taken longer than the anticipated period as the construction work remained stagnant for few years.

\subsection{Seasonal flow.}

Since Kalimpong is the hill station, it is regularly visited by domestic and international tourist. During the peak seasons, the traffic congestion becomes acute causing delays for students, servicemen, regular public etc.

\subsection{Underdeveloped pavements.}

Another reason for traffic congestion is underdeveloped pavements. The pavements along the roads that are meant for public are either very narrow or damaged in numerous places, people prefer to walk on the road thus causing more distress.

\subsection{Encroachment of footpaths.}

Another reason why people prefer to walk on the road is the encroachment of the footpaths by small shops, illegal extension of the shops like clothing shops, ration shops, household essential shops, pan shops etc.

\section{PERCEPTION STUDY ON THE PROBLEM}

A perception study was also conducted on the people including the students and the people traversing the town by foot to see if people were aware of the problems and the factors responsible for it.

\subsection{Means of transportation adopted by people surveyed}

Table3. Datasheet to show the means of transportation adopted by the surveyed people.

\begin{tabular}{|l|l|l|l|l|}
\hline $\begin{array}{l}\text { Means of } \\
\text { transportation }\end{array}$ & Foot & Two-wheeler & Service vehicle & Private vehicle \\
\hline $\begin{array}{l}\text { Number of } \\
\text { persons in } \%\end{array}$ & 23 & 17 & 23 & 37 \\
\hline
\end{tabular}

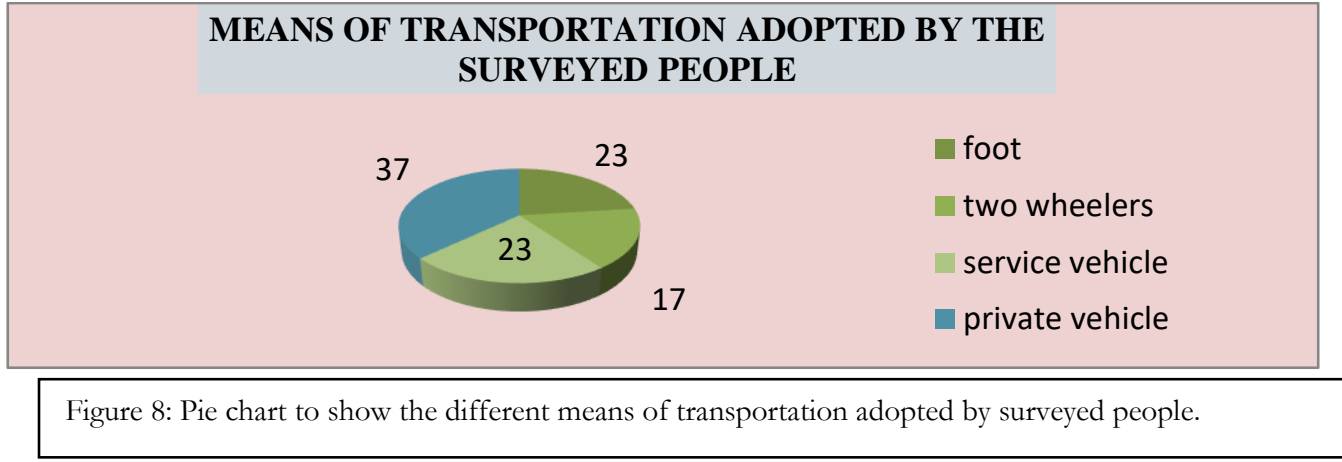

The total of 50 people was surveyed in Kalimpong main road, Kaanchan cinema road and Kalimpong motor stand. Out of these $23 \%$ travelled by foot and were mainly students living in and around the market area, $17 \%$ travelled by two wheelers (bike and scooty). Similarly, $23 \%$ of them availed service vehicles or 
Addressal to the Rising Problem of Traffic Congestion in Kalimpong, West Bengal: Causes and Preventive Measures

taxis as as they did not have their own while $37 \%$ of them had their own private vehicle (Table 3, and Figure 8).

From the data provided it can be clearly seen that when $37 \%$ of the people travelled to the town in their private vehicle, the parking of the vehicle is also required as one cannot simply move around in their cars for whatever work they have come to Kalimpong town to be done, thus, the parking is required and Kalimpong doesn't have a separate space for parking of private vehicles, thus illegal parking surfaces.

\subsection{Responses to see whether people consider traffic congestion as one of the major problems in Kalimpong or not.}

Table4. datasheet to show the responses of the survey people against traffic congestion.

\begin{tabular}{|l|l|}
\hline Response & Number of responses in \% \\
\hline Agree & 88 \\
\hline Disagree & 4 \\
\hline Neutral & 8 \\
\hline
\end{tabular}

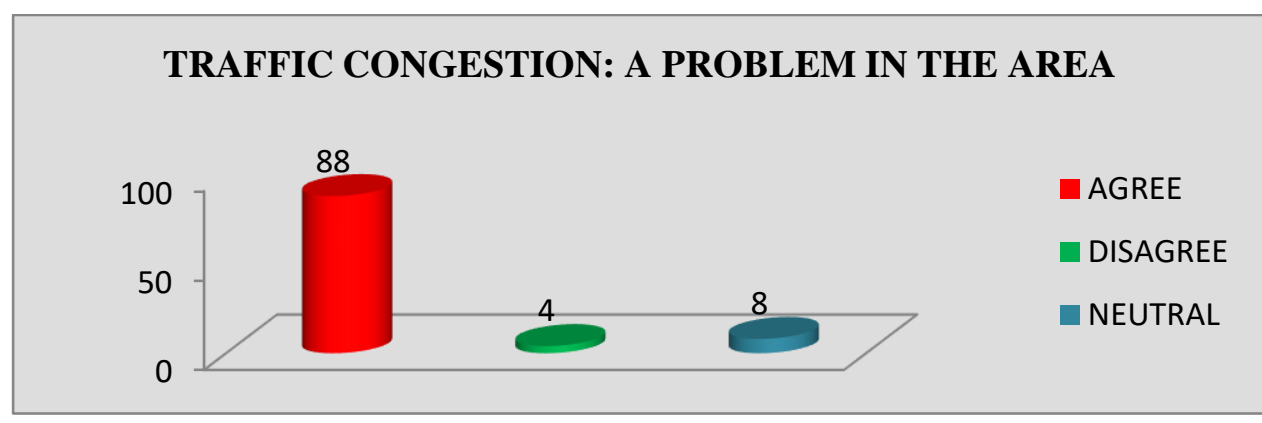

Figure 9: Bar graph to show the responses of people towards traffic congestion in the area.

To see whether the people are aware of the ongoing problems of traffic congestion in the town, the surveyed people were also question as to whether they agree or disagree that Kalimpong was facing the problem of traffic congestion. $88 \%$ of them agreed to the prevalence of the situation, while only $4 \%$ disagreed and remaining $8 \%$ remained neutral (table 4, and Figure 9).

\subsection{Responses towards different factors leading to traffic congestion}

Again, to find out what people have observed as the factors causing traffic congestion in the town, four most suitable factors were given and they just had to agree whether it was the reason or not.

Clearly $100 \%$ of them agreed that small sized roads of Kalimpong plus road side parking were the reasons for the problem. $86 \%$ and $78 \%$ of them agreed that the increase in number of private vehicles and limited space for parking were the contributing factors (Table 5, and Figure 10).

Table5. datasheet to show responses regarding the factors responsible for traffic congestion

\begin{tabular}{|l|l|l|l|l|}
\hline Factors & $\begin{array}{l}\text { Limited space for } \\
\text { parking }\end{array}$ & Small sized road & Roadside parking & $\begin{array}{l}\text { Increase in } \\
\text { number of private } \\
\text { vehicles }\end{array}$ \\
\hline Responses in $\%$ & 78 & 100 & 100 & 86 \\
\hline
\end{tabular}




\section{FACTORS RESPONSIBLE FOR TRAFFIC CONGESTION}

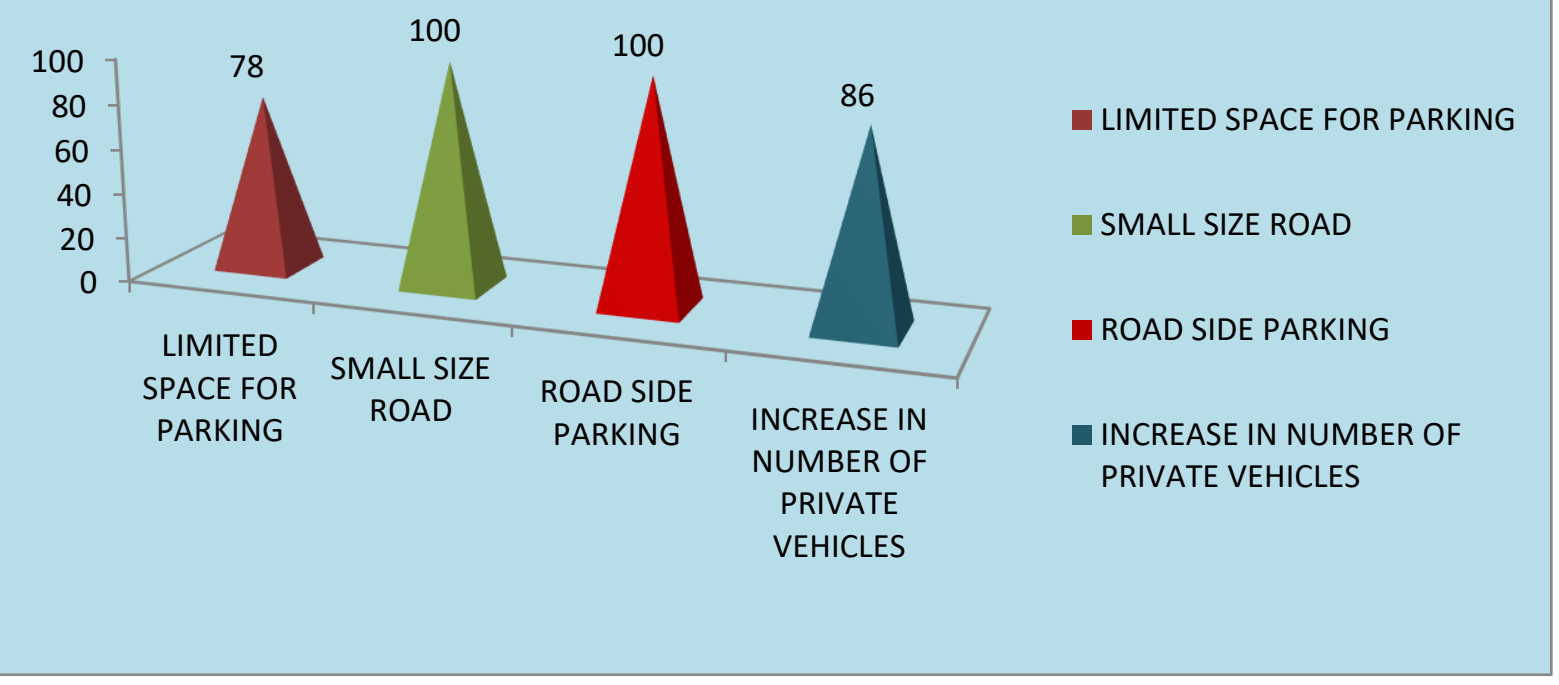

Figure 10: Graph showing people's responses towards different factors responsible for traffic

Thus, it can be clearly seen that illegal parking caused by narrow roads and absence of parking spaces and recent increase in the number of private vehicles have aggravated the problem causing chaos and havoc in this small hill station.

\section{Consequences of Traffic Congestion}

Due to the arising problems of traffic congestion, Kalimpong faces numerous consequences in their everyday lives. "Time is money", however since so much time is wasted the mentioned quote sounds vague. The people often complain about the amount of time that is wasted. In order to avoid the traffic problem, people often leave their houses early leaving many works undone. Similarly, 'To be delayed' is a common happening for the people of Kalimpong. Usually students leaving for their schools or colleges are delayed as these educational institutes are located at the outskirts of the town. Traffic congestion has also led to noise pollution as vehicles have to "stand still" for several minutes or hours because of the various activities like blowing of the horn, shouting, playing of the music- which all in all produces unpleasant noises bring distress upon the people. Air pollution is another happening of the congestion. Since vehicles are kept on standby, the amount of smoke it releases pollutes the air. Whenever vehicles are kept on standby, fuel is also wasted which will cause the depletion of the already in short resources. And lastly, often minor accidents do take place in the town like one car been hit by the other, two wheelers been hit, people getting hit by vehicles etc.

\section{Suggestive Preventive Measures to Avoid the Problem of Traffic Congestion}

On the basis of the study of the Kalimpong town and its situation, following preventive measures can be undertaken to bring some relief from problems related to traffic.

\subsection{Completion of the parking complex}

The parking complex that is yet to be completed, can be completed soon if the concerned authorities can look after the rigidities causing stagnation of the construction. 
Addressal to the Rising Problem of Traffic Congestion in Kalimpong, West Bengal: Causes and Preventive Measures

\subsection{Strict and severe penalties against illegal parking}

Penalties have to be strictly imposed on the practices of illegal parking. However since Kalimpong doesn't have any alternative spaces for parking of the vehicles, in some places like Kanchan cinema compound, main road, novelty road the parking can be carried forward but a certain time period must be framed for such parking and a proper system has to be followed and not to be done haphazardly.

\subsection{Prohibition of the vehicles coming from the other states inside the main town}

In the capital of the neighbouring state of Sikkim, Gangtok, the vehicles coming from the other states are strictly prohibited from entering the main town and a proper place is allocated for those vehicles at the outskirts. Similar steps can be followed to avoid traffic congestion. Vehicle coming from other state can be allocated parking space at the outskirts like $7^{\text {th }}$ mile or $8^{\text {th }}$ mile. This will not only help tackle traffic but will also boost the economy of the local taxi's drivers.

\subsection{Immediate pavement reconstructions}

The pavements that have been damaged have to be immediately reconstructed. Areas where pavements are absent have to be provided with one. People have to be encouraged to make use of pavements.

\subsection{Strict actions against pavement encroachment}

Shops that occupy the pavement by extending their shops, diurnal small shops along the pavements due to which people often avoid pavements should be strictly taken care by imposing penalties.

\subsection{Prohibiting heavy vehicles on the narrow road}

Heavy vehicles should be prohibited to make usage of the narrow road. An alternative has to be arranged for these vehicle (Rahane \& Saharkar, 2017).

\section{Conclusion}

To make Kalimpong free from the problems of the traffic is not the responsibility of authorities alone; rather it is a collective effort that has to be made by the public and the authorities. The people have to be made aware of the problems and not to turn deaf ear. If the problem of traffic congestion is not addressed and tackled now, the problem might accelerate and be out of hands resulting into severe consequences. The authorities have to strictly look after the practice of illegal parking along the narrow roads and come up with new parking complex be it large or small. People have to act responsible. The above-mentioned preventive measures can be followed to tackle the problem. Once the problem is addressed and worked upon it is not impossible to overcome the problem and make Kalimpong free from traffic congestion.

\section{Competing Interests}

I have no conflict of interest to declare for this paper. I shall bear the full responsibility for the submission.

\section{How to Cite this Article:}

Subba, R. (2020). Addressal to the Rising Problem of Traffic Congestion in Kalimpong, West Bengal: Causes and Preventive Measures. Advanced Journal of Social Science, 7(1), 60-70. https://doi.org/10.21467/ajss.7.1.60-70

\section{References}

Maji,S. May 2017. "Traffic Congestion and Possible Solutions, A Case Study Of Asansol. Journal Of Research In Humanities And Social Sciences, Vol. 05, Pp. 42-46.

Marve,S.R., Bhorkar,M., Baitule,P. Special Issue 2016. "Traffic Congestion Minimization Study For Hingna Area Of Nagpur City, MS. India". International Journal of Engineering Research And Technology.

Rahane,S.K, Saharkar, 2017 U. R. “Traffic Congestion- Causes And Solutions: A Case Study Of Talegaon Dabhade City”. Journal of Information, Knowledge And Research In Engineering.

Rao. A. M., Rao. K. R., 2012, Measuring Urban Traffic Congestion - A Review, International Journal for Traffic and Transport Engineering. 
Rosemary Subba, Adv. J Social Sci.; Vol. 7, Issue 1, pp: 60-70, 2020

Sarkar,D., 2013, Structural Analysis of Existing Road Networks of Cooch Behar District, West Bengal, India: A Transport Geographical Appraisal, Ethiopian Journal of Environmental Studies and Man.

Suresh, B., Rao, N. V., Baraik,S. May 2018 Volume ,Issue 5. "Research On Urban Road Traffic Congestion Of Hyderbad A Case Study". International Journal of Civil Engineering Technology (IJCIET)

Umoren, V., Ikurekong, E. E., Emmanuel, A \& Udida, A. A., 2009, Development Envelopment of Road Infrastructure as a Tool of Transforming Ibiono Ibom Local Government Area, Global Journal of Social Sciences, 8(2), 53-59.

Vencataya. L., Pudaruth. S., Dirpal. G., Narain. V., 2018, Assessing the Causes \& Impacts of Traffic Congestion on the Society, Economy and Individual: A Case of Mauritius as an Emerging Economy, Studies in Business and Economics, University of Mauritius, Mauritius.

Ye,S. 2012 “"Research On Urban Road Traffic Congestion Charging Based On Sustainable Development”. International Conference on Applied Physics and Industrial Engineering.

Publish your research article in AIJR journals-

* Online Submission and Tracking

* Peer-Reviewed

* Rapid decision

* Immediate Publication after acceptance

* Articles freely available online

* Retain full copyright of your article.

Submit your article at journals.aijr.in
Publish your books with AIJR publisher-

* Publish with ISBN and DOI.

* Publish Thesis/Dissertation as Monograph.

* Publish Book Monograph.

* Publish Edited Volume/ Book.

* Publish Conference Proceedings

* Retain full copyright of your books.

Submit your manuscript at books.aijr.org 